\title{
Advanced Small Intestinal Large Cell Neuroendocrine Carcinoma
}

National Cancer Institute

\section{Source}

National Cancer Institute. Advanced Small Intestinal Large Cell Neuroendocrine

Carcinoma. NCl Thesaurus. Code C156689.

A small intestinal large cell neuroendocrine carcinoma that has spread extensively to other anatomic sites or is no longer responding to treatment. 